\title{
STRATEGI PENGEMBANGAN DESTINASI WISATA DESA BONGO, KABUPATEN GORONTALO
}

\author{
Ramang Husin Demolingo \\ Email: rlinggo@gmail.com
}

\begin{abstract}
This study analyzes the development strategy of Bongo Village, Gorontalo District, Sulawesi, as a tourism destination. This village has a great potential of natural and cultural resources but it has not fully developed yet as tourist attractions. The study starts by identifying tourism potential of the village and followed by setting up the strategy to develop the village as a attractive tourism destination. This study used qualitative descriptive data analysis and SWOT analysis. The result shows that tourism potentials of the Bongo village includes natural tourism resources, artificial resources, cultural and social economic potential, accessibility and supporting facilities, which have not been used and managed well. In addition, some public facilities and infrastructure are inadequate. This study suggests that there is a need for the government involvement in establishing an institution of tourism management, improving the quality of human resources, building infrastructure of tourist facilities which are still lacking, as well as forming a close cooperation between tourism stakeholders including the community.
\end{abstract}

Keywords : Tourism Potential, Development Strategy, Community, Bongo Village

\section{Pendahuluan}

Indonesia merupakan daerah yang sangat luas, terdiri dari lebih dari 17 ribu pulau, dan tiap-tiap daerahnya memiliki potensi alam yang indah dan budaya yang unik. Keindahan alam dan budaya lokal itu merupakan potensi besar untuk dikembangkan sebagai daya tarik wisata dan dikelola sebagai salah satu sumber daya ekonomi masyarakat setempat. Dalam beberapa hal, pariwisata juga memberikan kontribusi dalam pengentasan kemiskinan (Putra dan Pitana 2010). Sejauh ini, belum semua potensi wisata daerah-daerah di Nusantara dikembangkan dengan baik. Persoalannya adalah belum semua daerah memiliki akses yang memadai, sementara itu 
semangat rintisan kurang kuat. Salah satu cara untuk mengatasi hal ini adalah mendesaknya disusun langkah strategis untuk pemanfaatan sumber daya alam untuk pariwisata.

Pemerintah perlu turut serta mendorong terbentuknya badan pengelola destinasi wisata di daerah-daerah. Badan ini akan bertugas untuk mengoptimalkan sumber daya untuk mendorong terwujudnya harapan mendatangkan wisatawan, penyediaan jasa, dan menciptakan lingkungan yang mampu mendukung terwujudnya kegiatan dalam bentuk kebijakan, peraturan, dan insentif (Hermantoro, 2011:22).

Desa Bongo, terletak $10 \mathrm{~km}$ dari Ibu Kota Provinsi Gorontalo, salah satu Provinsi baru di Sulawesi bagian utara. Provinsi ini merupakan satu daerah yang memiliki potensi sumber daya alam (SDA) yang menakjubkan. Sumber daya alam itu antara lain pegunungan, yang sering dijadikan objek perkemahan atau pun kegiatan-kegiatan wisata seperti outbound. Di desa ini juga terdapat lahan perkebunan yang luas, karena sebagian dari masyarakat Desa Bongo merupakan petani. Wisatawan dapat menyaksikan sekaligus ikut berkebun dengan masyarakat di lahan perkebunan yang terletak di bukit-bukit desa.

Keindahan pantai Dulanga sebagai tempat para wisatawan lokal berekreasi menikmati keindahan laut. Sementara untuk potensi sumber daya buatan (SDB) seperti potensi saujana berupa Masjid Walima Emas yang terletak di atas bukit Desa Bongo; Museum Goa dan Museum Batu; Pasar Tradisional atau Pasar Subuh; Tarian Longgo Tulaibala (seni tari bela diri); Tarian Saronde dan Tidi, biasa dipentaskan pada upacara adat pernikahan; Budaya Dikili, Dikili (dzikir dalam bahasa daerah Gorontalo) oleh masyarakat desa yang dapat dinikmati oleh wisatawan setiap malam Jumat di pondok pesantren Desa Bongo.

Potensi budaya unggulan yang dimiliki oleh Desa Bongo sebagai aset budaya masyarakat Islam Gorontalo yaitu tradisi perayaan Walima (tradisi masyarakat desa dalam perayaan hari kelahiran Nabi Muhammad SAW) yang dilaksanakan setiap tanggal 12 Rabiul Awal Tahun Hijriah atau setiap bulan Januari-Februari setiap tahunnya dalam kalender Masehi. Umat Muslim di Indonesia mengenal perayaan hari kelahiran Nabi Muhammad SAW tersebut dengan istilah Maulid sehingga sangat menarik bagi para wisatawan yang ingin mengetahui dan mempelajari tentang sejarah kerajaan dan tradisi budaya Islam yang ada di Gorontalo (Laporan PKBM YOTAMA, 2007).

Desa Bongo letaknya sangat strategis karena berdekatan dengan tempattempat wisata lainnya. Letak seperti ini akan menarik jika dikemas menjadi produk perjalanan wisata. Objek wisata yang berdekatan dengan Desa Bongo di antaranya Tangga Dua Ribu yang berada di Teluk Kota Gorontalo. Objek ini selalu ramai dikunjungi wisatawan karena pantainya yang indah 
dan merupakan pusat jajanan kuliner Gorontalo. Daya tarik lainnya adalah objek wisata Pantai Biluhu yang berada di Desa Biluhu, yang menawarkan pantai dan tebing-tebing yang indah; Objek Wisata Tanjung Kramat berada di Desa Tanjung Kramat, dikenal dengan Goa LO Milate. Objek wisata ini berada di tepi pantai dan sebagai tempat pemakaman para wali di daerah Kota Gorontalo.

Pengembangan pariwisata yang ideal akan selalu menunjukkan kepedulian terhadap pelestarian lingkungan, melibatkan pemerintah dan masyarakat lokal. Pengembangan pariwisata yang melibatkan masyarakat sangat penting untuk membuka lapangan kerja, memberikan pemahaman tentang pariwisata, dan meningkatkan kondisi perkonomian masyarakatnya. Pariwisata memiliki prospek yang sangat besar jika dikembangkan dengan baik, melalui pembenahan sarana dan prasarana serta partisipasi masyarakat. Untuk dapat mengembangkan dan memajukan kegiatan pariwisata tersebut, diperlukan sebuah pengelolaan yang baik dengan didukung oleh sumber daya manusia yang ahli, berpengalaman, dan berkomitmen dalam bidang pariwisata.

Terbatasnya fasilitas pendukung menjadi hambatan pelaksanaan kegiatan pariwisata di Desa Bongo. Wisatawan masih enggan untuk mengunjungi atau pun berlama-lama berada di desa ini karena segala sesuatu yang mungkin mereka butuhkan belum tersedia. Hal ini juga yang dapat memicu rendahnya angka wisatawan yang berkunjung ulang sebagai repeater tourist.

Pada dasarnya pengembangan pariwisata di Desa Bongo sangat penting untuk dilakukan. Pengembangan pariwisata di Desa Bongo akan memberikan perubahan dan keberlangsungan baik jangka pendek maupun jangka panjang bagi masyarakat lokal dan pemerintah Gorontalo.

Berdasarkan latar belakang masalah tersebut, maka masalah penelitian ini dirumuskan sebagai berikut: apa potensi pariwisata Desa Bongo Kecamatan Batudaa Pantai Kabupaten Gorontalo dan bagaimana strategi pengembangan potensi tersebut sehingga Desa Bongo dapat menjadi destinasi wisata yang mampu menarik banyak wisatawan.

\section{Teori dan Metode}

Teori yang digunakan untuk menjawab persoalan di atas adalah pengembangan pariwisata dan teori siklus hidup destinasi wisata. Teori pengembangan pariwisata yang relevan adalah pengembangan objek dan daya tarik wisata perdesaan yaitu dengan menggunakan community approach atau community based development. Hal ini disebabkan karena masyarakat lokal yang akan membangun, memiliki dan mengelola langsung fasilitas wisata serta pelayanannya, sehingga dengan demikian masyarakat dapat menerima secara langsung keuntungan ekonomi serta mencegah langsung terjadinnya urbanisasi. 
Dalam pengembangan, baik pengembangan destinasi, kawasan pariwisata, dan objek serta daya tarik wisata pada umumnya mengikuiti alur hidup pariwisata (Marpaung, 2002:49). Dalam proses pengembangan pariwisata, perencanaan matang dan strategis sangat diperlukan. Menurut Mill (2000: 193), bila tidak adanya perencanaan pada sebuah tempat tujuan wisata dapat berakibat negatif pada daerah tersebut.

Teori siklus hidup destinasi wisata (tourism destination lifecycle) yang diperkenalkan oleh Richard Butler tahun 1980 adalah konsep hipotetik untuk memahami evolusi atau perkembangan dari sebuah destinasi pariwisata. Pembabakan evolusi ditakar dengan dua hal yaitu jumlah wisatawan yang berkunjung ke suatu objek dan rentang waktu perjalanan evolusi destinasi.

Untuk mengetahui perumusan pengembangan pariwisata terhadap objek dan daya tarik wisata maka sangat diperlukan suatu tahapan dimana pengembangan pariwisata tersebut mampu berdiri sekarang ini. Tahapan pengembangan pariwisata membawa implikasi serta dampak yang berbeda. Menurut Richardson dan Fluker, (2004: 51) yang dimaksud dengan model siklus hidup destinasi (destination lifecycle model) adalah sebagai berikut:

A model that characterises each stage in the lifecycle of a destination (and destination areas and resort area) including introduction, growth, maturity, and decline and/or rejuvenation.

Seperti ditegaskan dalam kutipan di atas, siklus hidup daerah wisata ditandai dalam beberapa tahap yaitu tahap pengenalan (introduction), pengembangan (growth), pematangan (maturity), dan dari sini ada dua kemungkinan yaitu penurunan (decline) karena kejenuhan atau peremajaan (rejuvenation). Kelengahan dalam mengelola suatu destinasi akan menyebabkan penurunan, ditandai dengan ditinggalkannya destinasi tersebut oleh wisatawan, namun sebaliknya kesungguhan dan inovasiinovasi pengelolaan akan memungkinkan destinasi tersebut untuk tetap memikat wisatawan.

Selain dengan pengamatan, metode yang diterapkan dalam penelitian ini adalah melakukan wawancara dengan informan, focus group discussion (FGD), dan studi dokumentasi. Data yang diperoleh dianalisis dengan teknik analisis deskriptif kualitatif dan analisis SWOT.

\section{Potensi Pariwisata di Desa Bongo}

Seperti sudah disebutkan sepintas di awal tulisan ini, potensi wisata Desa Bongo, demikian banyak dan bisa dikategorikan menjadi tiga yaitu potensi wisata alam, budaya, dan potensi buatan. Masing-masing dari potensi itu didata per kelompok berikut ini. 


\subsection{Potensi Wisata Alam}

a) Aktivitas Alam. Pegunungan di Desa Bongo Kecamatan Batudaa Pantai Kabupaten Gorontalo merupakan pegunungan tempat aliran sungai bawah tanah yang cukup banyak. Keindahan alam pegunungan menjadi modal bagi pengembangan pariwisata Desa Bongo. Para wisatawan berkesempatan menambah pengalaman mereka dengan melakukan hiking dan rekreasi alam lainnya di pegunungan.

b) Aktivitas Pertanian. Pertanian di Desa Bongo bukan merupakan mata pencaharian utama bagi masyarakat Desa Bongo. Aktivitas pertanian yang dilakukan adalah jenis pertanian lahan kering. Kegiatan pertanian merupakan daya tarik wisata selain potensi ekologis. Kegiatan pertanian di Desa Bongo masih menggunakan cara-cara tradisional, dengan menggunakan cangkul untuk mengerjakan kebun, selain itu karena lahannya yang berbukit-bukit. Kegiatan yang masih tradisional inilah menjadi daya tarik bagi wisatawan, karena dianggap unik sehingga memunculkan keingintahuan mereka terhadap aktivitas masyarkat tersebut. Lahan dan bibit telah disiapkan oleh masyarakat Desa Bongo.

c) Aktivitas Nelayan. Aktivitas nelayan merupakan mata pencaharian utama bagi masyarakat Desa Bongo. Potensi laut dan pantai Dulanga merupakan sumber daya andalan. Pantai Dulanga ini mempunyai pasir putih dan ombak yang tenang karena berada di Teluk Tomini. Wisatawan bisa melakukan kegiatan snorkeling di pantai ini karena lautnya yang tenang, dapat menikmati keindahan laut, serta bisa ikut dengan para nelayan yang sedang menangkap ikan. Wisatawan juga dapat menikmati suasana sunset di pesisir Pantai Dulanga. Mayoritas pengunjung pantai ini adalah wisatawan lokal. Daya tarik pantai ini adalah pantai yang berpasir putih dan tempat menyaksikan sunset bersama nelayan Desa Bongo. Adapun suasana aktivitas di Pantai Dulanga seperti Gambar 1.

\subsection{Potensi Sumber Daya Buatan}

Masjid Walima Emas dan bentang alam. Masjid ini terletak di atas bukit, dengan pemandangan laut Teluk Tomini yang indah. Laut biru dan nyiur melambai membuat bentang alam tropis yang mewujudkan saujana alam dan arsitektur yang mengagumkan (Foto 2). Bentuk masjid ini merupakan campuran arsitektur modern dengan budaya lokal masyarakatnya. Masjid ini dibangun tahun 2007 oleh yayasan PKBM YOTAMA, dapat menampung 99 orang jamaah. Turis yang berkunjung ke masjid ini adalah wisatawan lokal yang ingin beribadah dan menikmati keindahan alam di atas bukit dengan pemandangan laut-Nya. Biasanya masjid ini rame di kunjungi oleh wisatawan setiap hari Jumat dan pada hari perayaan Walima. Masjid ini 


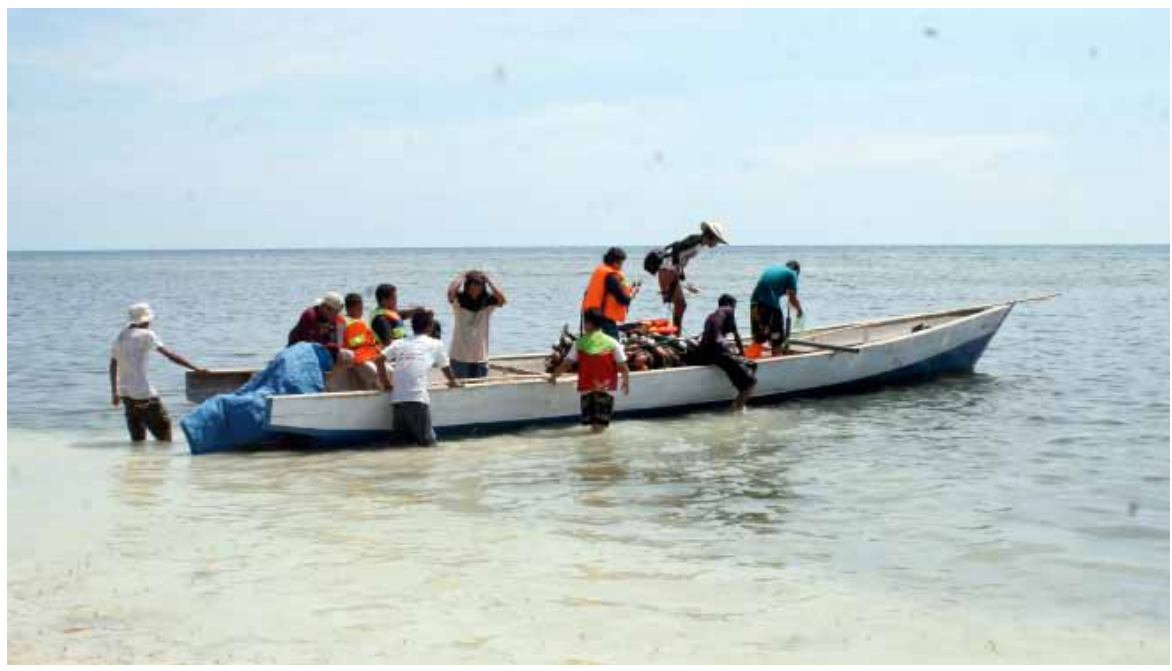

Foto 1 Aktivitas Nelayan Desa Bongo yang dimanfaatkan sebagai destinasi wisata untuk menikmati suasana sunset di Pantai Dulanga (Dokumentasi Peneliti, 2014)

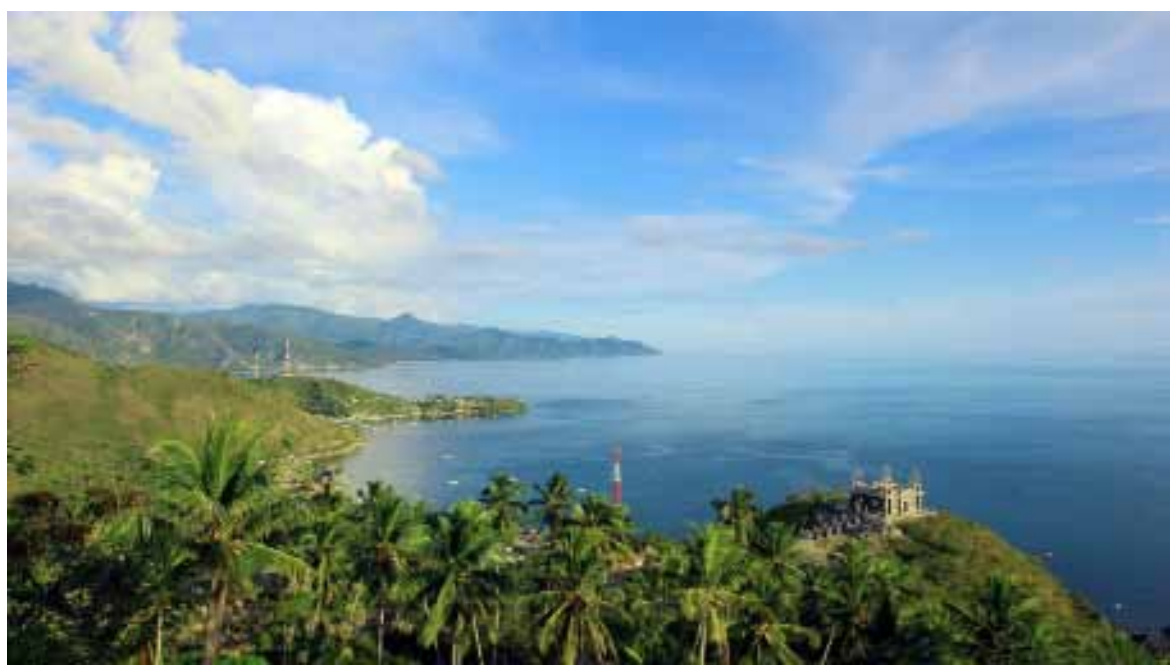

Foto 2 Potensi Saujana Masjid Walima Emas (Dokumentasi PKBM YOTAMA, 2012)

merupakan masjid yang pertama di pulau Sulawesi yang di bangun di atas bukit dengan pemandangan laut yang indah. Jarak dari Kota Kabupaten $22 \mathrm{~km}$, bisa ditempuh sekitar 60 menit dengan kenderaan roda dua dan roda empat. Selama perjalanan menuju tempat ini anda bisa menikmati pemandangan alam yang sangat indah.

Masjid ini menjadi pusat kegiatan keagamaan dan kebudayaan bagi para santri yang mondok di pesantren alam bubohu yang ada di Desa Bongo. Seperti kegiatan belajar mengaji, tafsir Al-qur'an, dan dakwah. Atraksi budaya yang di lakukan di masjid ini adalah Dikili, biasanya dilakukan sehari 


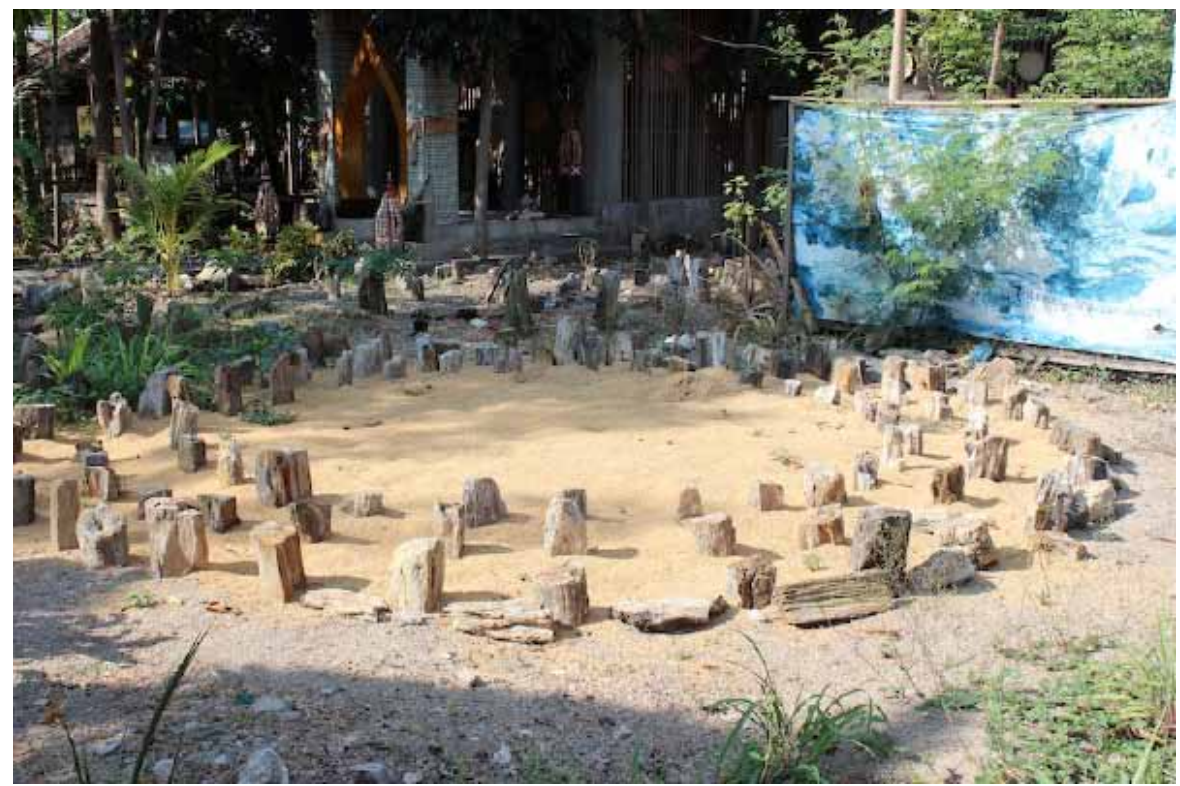

Foto 3 Potensi Sumber Daya Buatan Museum Goa dan Museum Batu(Dokumentasi PKBM YOTAMA, 2012)

semalam. Atraksi ini dapat dinikmati oleh wisatawan pada setiap malam Jumat dan pada malam-malam menjelang perayaan Walima setiap tahun. Kegiatan keagamaan di masjid ini telah menjadi agenda rutin masyarakat Desa Bongo.

Museum Goa dan Museum Batu. Museum Goa dan Museum Batu adalah potensi buatan yang merupakan peninggalan masyarakat leluhur Desa Bongo. Museum Goa saat ini dimanfaatkan sebagai Museum Batu, selain itu ada beberapa buku peninggalan sejarah Desa Bongo. Benda bersejarah seperti batu yang telah berumur ratusan tahun dan foto-foto zaman Kerajaan Bubohu. Untuk dapat melestarikan goa ini maka pihak pengelola Desa Wisata yang ada di Desa Bongo memanfaatkannya dengan menjadikan museum untuk menyimpan barang-barang peninggalan purbakala Desa Bongo. Museum ini berada di tengah-tengah tempat tujuan wisata di Desa Bongo, tepatnya berada di komplek PKBM YOTAMA. Museum ini banyak di kunjungi oleh wisatawan khususnya para pelajar dan mahasiswa yang ingin belajar sejarah kerajaan bubohu di Gorontalo. Bisaanya tempat ini rame di kunjungi pada hari sabtu dan minggu dan tidak di pungut biaya masuk (Foto 3)

\subsection{Potensi Budaya}

Kesenian tradisional. Potensi seni budaya yang dapat dijadikan atraksi atau daya tarik wisata Desa Bongo adalah budaya Dikili. Dikili (dzikir dalam bahasa daerah Gorontalo), atraksi ini dapat disaksikan oleh wisatawan pada 
setiap malam Jumat di pondok pesantren yang ada di Desa Bongo. Berbagai jenis tarian tradisional seperti Tarian Longgo Tulaibala (seni tari bela diri), tarian ini biasanya dapat disaksikan pada saat menyambut tamu spesial seperti pejabat atau tamu agung.

Selain itu ada juga Tarian Saronde dan Tidi. Tarian ini biasa dipentaskan pada upacara adat pernikahan, dipersembahkan khususnya untuk pengantin pria dan wanita pada malam peminangan. Tarian ini adalah tarian adat dan wajib bagi kedua mempelai untuk memperagakan pada saat acara pernikahan. Seiring dengan perkembangan pariwisata di Gorontalo, tarian ini sudah menjadi bagian atraksi pada acara-acara besar seperti perayaan walima.

Atraksi Budaya Walima. Potensi budaya unggulan yang dianggap potensial dan dimiliki oleh Desa Bongo serta merupakan aset budaya masyarakat Islam Gorontalo yaitu tradisi Perayaan Walima. Tradisi ini merupakan perayaan hari kelahiran Nabi Muhammad SAW yang dilaksanakan setiap tanggal 12 Rabiul Awal Tahun Hijriah atau setiap tahun dilaksanakan pada bulan Januari dan Pebruari dalam kalender masehi. Umat muslim di Indonesia mengenal perayaan ini sebagai hari kelahiran Nabi Muhammad SAW dengan istilah Maulid. Perayaan ini sangat menarik bagi para wisatawan yang ingin mengetahui dan mempelajari tentang sejarah kerajaan dan tradisi budaya Islam yang ada di Gorontalo.

Dalam rangka melesatarikan kebudayaan yang ada di Desa Bongo pemerintah Kabupaten Gorontalo melakukan berbagai upaya. Salah satunya yaitu menyelenggarakan Festival Walima setiap tahunnya. Festival Walima ini merupakan acara kebudayaan turun temurun yang dilaksanakan setiap tahun. Kegiatan ini bertujuan untuk melestarikan dan memperkenalkan budaya dan adat istiadat setempat kepada para wisatawan yang berkunjung ke Desa Bongo (Foto 4).

Pasar Tradisional. Pasar tradisional adalah salah satu potensi sosial budaya yang ada di Desa Bongo. Pasar ini merupakan pasar subuh yang tradisional dan masih menggunakan sistem barter. Sistem ini menarik bagi para wisatawan yang ingin menikmati belanja tanpa menggunakan pembayaran dengan uang tunai melainkan menukarnya dengan barang. Pasar ini dibuka setiap hari Rabu dan Minggu dan dimulai pukul o4.00 sampai pukul 09.0o WITA. Waktu buka seperti ini sesuai dengan namanya pasar subuh.

\subsection{Fasilitas Pendukung Pariwisata}

Perkembangan destinasi pariwisata sangat dipengaruhi oleh beberapa fasilitas di antaranya fasilitas pendukung seperti transportasi, pendidikan, dan kesehatan. Adapun fasilitas pendukung adalah adanya sebuah Sekolah Menengah Kejuruan Pariwisata (SMK), lahan parkir yang luas dengan daya 


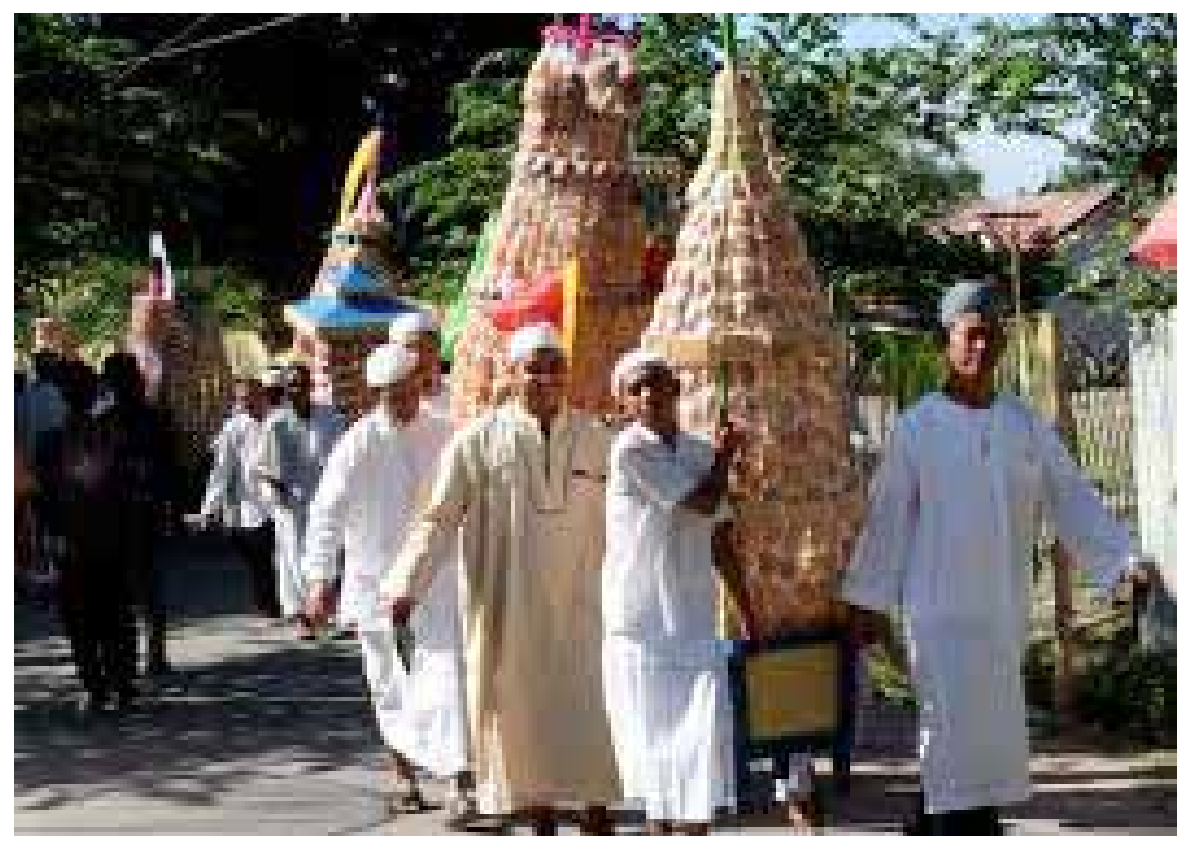

Foto 4. Atraksi Budaya berupa Festival Walima (Dokumentasi PKBM YOTAMA, 2012)

tampung hampir 300 jenis kendaraan roda dua dan roda empat, dan fasilitas toilet.

Sarana wisata merupakan kelengkapan daerah tujuan wisata yang diperlukan untuk menikmati perjalanan wisata ke Desa Bongo. Berdasarkan potensi alam dan budaya yang dimiliki Desa Bongo, kunjungan wisatawan dengan tujuan menikmati potensi yang masih alami semakin meningkat. Usaha pariwisata sudah mulai berkembang. Jumlah usaha pariwisata sampai saat ini ada empat penginapan berbentuk Walima (wombohe), satu restoran dan satu art shop.

Adapun pariwisata yang sudah ada di Desa Bongo, saat ini masih dikelola oleh yayasan PKBM YOTAMA. Desa Bongo belum mendapatkan keuntungan dari adanya usaha pariwisata ini, karena belum adanya pengelolaan yang mengatur secara resmi kontribusi dari kegiatan pariwisata di Desa Bongo. Untuk memberdayakan masyarakat lokal agar dapat berperan serta mengelola secara langsung kegiatan wisata dengan konsep ramah lingkungan, PKBM YOTAMA memiliki rencana membuat homestay untuk memberdayakan masyarakat secara langsung dan tidak langsung.

Masyarakat dipercayakan untuk mengelola homestay dan membentuk suatu badan pengelola yang bekerjasama dengan pemerintah Desa Bongo untuk mengatur usaha homestay. Hal ini untuk mengatisipasi salah satu potensi kunjungan wisatawan pada perayaan budaya Walima setiap tahun. Kehidupan masyarakat Desa Bongo yang mayoritas beragama Islam serta 


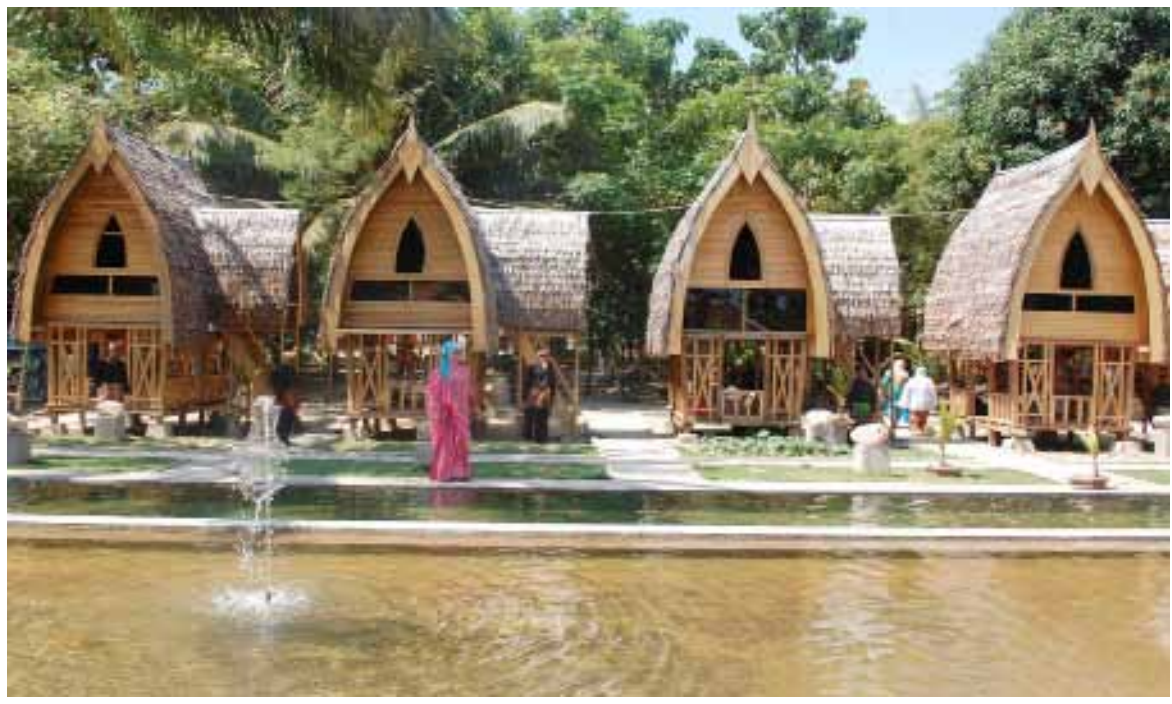

Gambar 5. Fasilitas Pendukung berupa penginapan (Wombohe). (Dokumentasi PKBM YOTAMA, 2012)

peran tokoh agama sangatlah penting dalam menjaga potensi sumber daya alam demi keberlanjutannya. Fasilitas-fasilitas pendukung seperti akomodasi yang dibangun dengan arsitektur unik bergaya lumbung dengan hiasan air mancur (Foto 5).

\subsection{Aksesibilitas}

Infrastruktur, merupakan salah satu aspek yang sangat penting seperti jalan yang menuju ke Desa Bongo yang dapat ditempuh hanya melalui dua arah, yakni jalur timur dan utara. Jalan yang menuju pusat pemerintahan desa dengan dusun-dusun yang ada di wilayah Desa Bongo sebagian besar jalan beraspal. Namun, jalan di jalur utara yang menghubungkan Desa Buhudaa dan Desa Bongo mengalami kerusakan yang cukup parah dan perlu mendapat perhatian pemerintah daerah untuk segera dilakukan perbaikan. Kerusakan jalan ini membuat terganggunya kenyamanan perjalanan wisatawan yang menuju Desa Bongo. Adapun aksessibilitas seperti dalam Foto 6.

\section{Srategi Pengembangan Bongo sebagai Destinasi Wisata}

Agar dapat merumuskan strategi pengembangan destinasi wisata dan peningkatan kunjungan wisatawan yang tepat terhadap destinasi pariwisata di Desa Bongo, perlu diketahui fase-fase perkembangan pariwisata sesuai dengan teori yang digunakan dalam penelitian ini yaitu teori siklus hidup destinasi yang diperkenalkan Butler (1980). Terdapat tujuh fase perkembangan pariwisata yaitu penemuan (exploration), keterlibatan (involvement), pembangunan (development), konsolidasi (consolidation), 


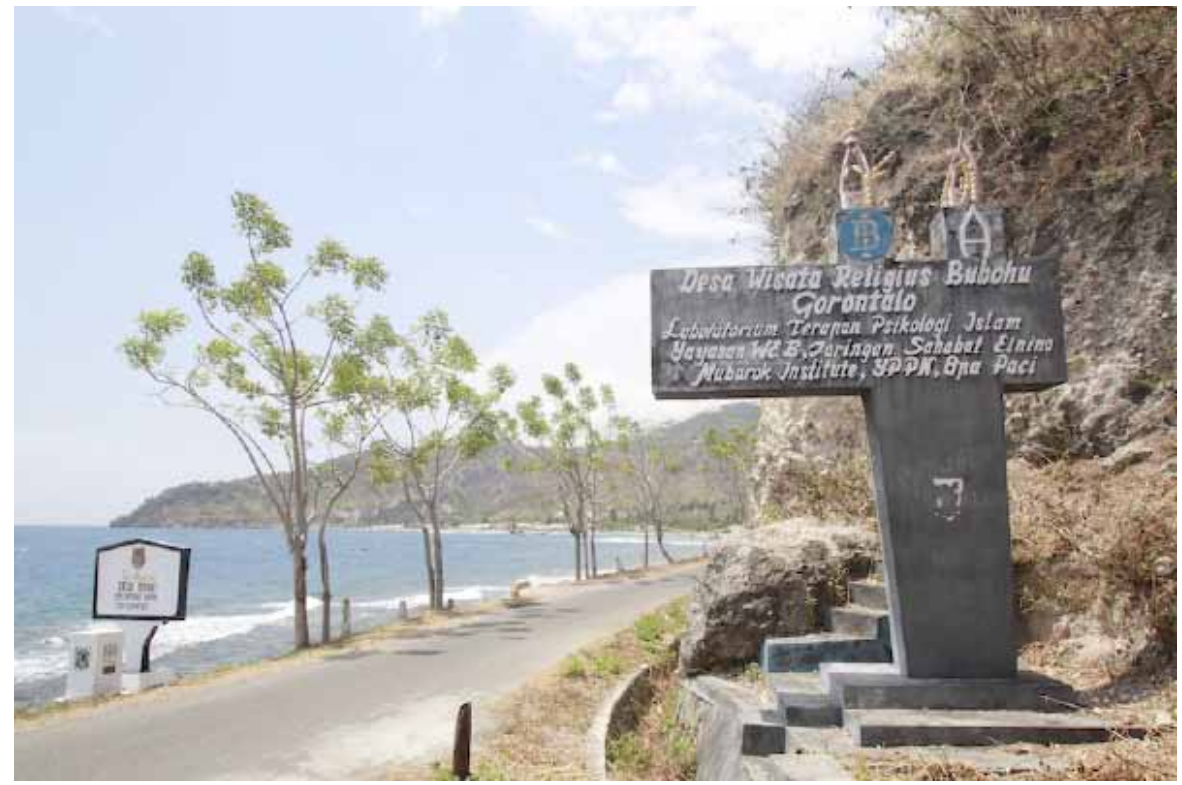

Foto 6. Akses Jalan menuju Pintu Gerbang Desa Bongo (Dokumentasi Peneliti, 2014)

stagnasi (stagnation), penemuan (decline), dan peremajaan (rejuvenation). Setelah dilakukan pengamatan maka destinasi pariwisata Desa Bongo tergolong ke dalam fase involvement (keterlibatan) yaitu fase kedua yang ditandai dengan meningkatnya jumlah kunjungan wisatawan. Dari fase keterlibatan hingga sekarang mulai berkembang ketahap selanjutnya yaitu fase pembangunan, yang sesuai dengan siklus hidup destinasi dan strategi pengembangan pariwisata.

SWOT merupakan pendekatan yang digunakan untuk merumuskan srategi pengembangan dan peningkatan kunjungan wisatawan ke Desa Bongo. Sesuai dengan kondisi dan keadaan Desa Bongo, hal ini berdasarkan pada memaksimalkan kekuatan (Strengths) dan peluang (Opportunities), namun secara bersamaan dapat meminimalkan kelemahan (Weaknesses) dan ancaman (Threats) (Rangkuti, 2005:19). Berikut ini diuraikan pendekatan SWOT untuk mengkaji kondisi internal dan eksternal Desa Bongo dalam pengembangan pariwisata.

\subsection{Analisis Internal}

\section{a) Kakuatan}

Kekuatan adalah segala sesusatu yang dapat dikembangkan sebagai andalan pengembangan dan peningkatan kunjungan wisatawan ke Desa Bongo meliputi potensi ekologis, sumber daya buatan, potensi budaya dan sosial ekonomi, sehingga nantinya bisa bersaing dengan tujuan wisata lain. Variabel-variabel yang menjadi pedoman dalam melihat kekuatan yang 
dimiliki terdiri atas kondisi alam Desa Bongo, kondisi suhu yang cukup baik, atraksi Budaya Walima, tingkat aksesibiltas, keramah-tamahan penduduk, dan dukungan masyarakat lokal dan partisipasi pemerintah.

\section{b) Kelemahan}

Kelemahan merupakan suatu keadaan pada objek yang kurang menguntungkan dalam pengembangan pariwisata Desa Bongo melalui beberapa atraksi yang berbasis masyarakat. Kelemahan ini perlu diatasi sehingga layak dikembangkan dan tidak memberikan dampak negatif terhadap faktor dari luar yang mempengaruhi faktor eksternal tersebut yaitu kurangnya produk kerajinan lokal, kurangnya minat/ perhatian masyarakat terhadap pengembangan pariwisata pantai dan pertanian, kurangnya infrastruktur yang menunjang pariwisata, rendanya Sumber Daya Masyarakat lokal, tidak adanya pengelola resmi oleh masyarakat lokal, dan tidak adanya bantuan dari Pemerintah.

\subsection{Analisis Eksternal}

\section{a) Peluang}

Peluang merupakan segala sesuatu yang memberikan kesempatan untuk meningkatkan pengembangan Desa Bongo. Adapun peluang yang dimaksud yaitu kemajuan teknologi dan transportasi, pariwisata dunia, segmen pasar yang kuat dan adanya sekolah SMK Pariwisata.

\section{b) Ancaman}

Ancaman merupakan dampak negatif yang akan ditimbulkan dari faktorfaktor eksternal yang harus diantisipasi agar tidak menimbulkan kerugian terhadap pengembangan pariwisata di Desa Bongo. Yang termasuk ancaman tersebut di antaranya persaingan produk wisata/destinasi lain, rusaknya lingkungan; pengaruh budaya luar, ketergantungan yang berlebihan pada pariwisata, naiknya harga tanah/lahan, isu keamanan nasional.

\section{Strategi Pengembangan Pariwisata Desa Bongo}

Berdasarkan analisis pada faktor internal dan eksternal dengan menggunakan matrik SWOT dapat dirumuskan beberapa strategi seperti Strategi SO (Strengths Opportunities), Strategi WO (Weaknesess Opportunities), Strategi ST (Strenghts Threats), Strategi WT (Weaknesses Threats) yang merupakan kombinasi fakta - fakta dari internal dan eksternal. Selanjutnya diuraikan setiap strategi yang akan digunakan dalam pengembangan pariwisata di Desa Bongo adalah seperti berikut.

Strategi SO. Merupakan strategi yang menggunakan kekuatan untuk memanfaatkan peluang antara lain merancang paket atraksi wisata seperti paket atraksi Budaya Walima dan paket wisata pantai dan pertanian, 
meningkatkan promosi daya tarik wisata diantaranya memperluas pangsa pasar lewat media cetak dan elektronik dan melakukan promosi melalui Biro Perjalanan Wisata.

Srategi ST merupakan strategi yang menggunakan kekuatan untuk mengatasi ancaman antara lain perencanaan pengembangan, menyusun regulasi yang mengatur dan membatasi pembangunan yang daapat merusak potensi ekologis, di antaranya membentuk lembaga pengawas konservasi lingkungan desa dan membentuk lembaga adat, meningkatkan keamanan dan kenyamanan kawasan destinasi wisata seperti menjaga keamanan di lingkungan pariwisata Desa Bongo dan menciptakan kewaspadaan terhadap teroris.

Strategi WO merupakan strategi yang meminimalkan kelemahan untuk memanfaatkan peluang, antara lain meningkatkan kualitas sumber daya manusia melalui pengadaan pelatihan pariwisata kepada masyarakat lokal dan pengadaan sekolah menengah kejuruan pariwisata (SMK Pariwisata), revitalisasi budaya dan kerajinan lokal seperti menghidupkan/menggali budaya yang ada di Desa Bongo, meningkatkan produksi para pengrajin lokal, kerjasama antar pelaku usaha dengan tokoh lokal, dan keterlibatan masyarakat lokal.

Strategi WT merupakan strategi yang meminimalkan kelemahan untuk menghindari ancaman. Dari WT dapat diformulasikan beberapa strategi antara lain membentuk lembaga pengelolaan pariwisata Desa Bongo dan badan promosi pariwisata desa, menjaga kelestarian lingkungan dan konservasi alam Desa Bongo diantaranya menjaga kebersihan lingkungan, menjaga potensi ekologis dan keindahan alamnya, kontribusi pariwisata bagi perekonomian lokal (desa).

\section{Penutup}

Berdasarkan hasil pembahasan dan analisis data dari penelitian yang dilakukan maka dapat disimpulkan hal-hal sebagai berikut. Dalam penelitian ini beragam potensi pariwisata yang terdapat di Desa Bongo yang telah diindentifikasi menjadi daya tarik wisata di antaranya adalah potensi wisata alam yang terdiri dari aktivitas alam pegunungan, aktivitas pertanian, aktivitas nelayan; potensi sumber daya buatan berupa potensi saujana Masjid Walima Emas dan Meseum Goa/Batu; potensi budaya yaitu kesenian tradsional berupa tarian seni bela diri (Longgo Tulaibala), tarian pengantin (Saronde dan Tidi), dan budaya dzikir (Dikili); atraksi budaya tradisional masyarakat desa dalam merayakan kelahiran Nabi Muhammad SAW (Walima); pasar tradisional merupakan pasar subuh yang masih menggunakan sistem barter; fasilitas pendukung dengan adanya sarana wisata yang memadai seperti adanya sebuah sekolah menengah kejuruan pariwisata (SMK) dengan lahan parkir yang luas dan fasilitas toilet yang 
ada di dalamnya, empat penginapan berbentuk walima (wombohe), satu restoran dan satu art shop; aksessibilitas yang sangat mudah diakses oleh wisatawan yaitu dapat ditempuh melalui dua jalur darat dan satu jalur laut, jalur darat bisa di tempuh melalui jalur utara dan timur, untuk jalur laut bisa melalui Teluk Tomini.

Berdasarkan analisis internal dan eksternal dengan menggunakan matrik SWOT, dapat dirumuskan strategi inti untuk pengembangan destinasi wisata dan peningkatan kunjungan wisatawan ke Desa Bongo sebagai berikut. Strategi SO. Strategi SO merupakan strategi yang menggunakan kekuatan untuk memanfaatkan peluang menghasilkan strategi merancang paket atraksi wisata, meningkatkan promosi daya tarik wisata. Strategi ST. Strategi ST merupakan strategi yang menggunakan kekuatan untuk mengatasi ancaman menghasilkan strategi perencanaan dan pengembangan, membentuk/ membuat peraturan lokal yang mengatur dan membatasi pembangunan yang dapat merusak potensi ekologis, meningkatkan keamanan dan kenyamanan kawasan destinasi wisata. Strategi WO. Strategi WO merupakan strategi yang meminimalkan kelemahan untuk memanfaatkan peluang menghasilkan strategi meningkatkan kualitas sumber daya manusia (SDM), revitalisasi budaya dan kerajinan lokal, kerjasama antar pelaku usaha dan tokoh lokal. Strategi WT. Strategi WT merupakan strategi yang meminimalkan kelemahan untuk menghindari ancaman, menghasilkan strategi membentuk lembaga pengelolaan pariwisata, menjaga kelestarian lingkungan dan konservasi alam Desa Bongo, kontribusi pariwisata bagi perekonomian lokal.

Saran yang dapat direkomendasikan kepada pihak-pihak terkait dari hasil pembahasan adalah sebagai berikut. Pemerintah perlu membentuk suatu lembaga pengelola, meningkatkan kualitas sumber daya manusia, membangun infrastruktur pariwisata yang masih kurang. Untuk membangun infrastrukturt tersebut pemerintah dapat bekerja sama dengan investor. Bagi pengelola perlu adanya kerja sama yang baik antara pemerintah sebagai fasilitator, swasta (Yayasan pengelola PKBM YOTAMA), dan masyarakat lokal untuk bekerja sama sehingga kedatangan wisatawan dan segala aktivitas wisata yang berkembang di Desa Bongo dapat terkontrol dengan baik di bawah pengawasan masyarakat. Bagi masyarakat, perlu menjaga kebersihan dan keamanan lingkungan dengan mempertahankan keindahan potensi alam dan budaya yang ada di Desa Bongo.

\section{Ucapan Terimakasih}

Penulis menyampaikan ucapan terima kasih kepada Prof. Dr. Ir. I Made Antara, M.S. dan Dr. Ir. Syamsul Alam Paturusi, MSP., sebagai Pembimbing I dan Pembimbing II dalam riset dan penulisan tesis ketika menempuh program di Prodi S-2 Kajian Pariwisata, Universitas Udayana. Untuk Prof. I Nyoman Darma Putra, saya menyampaikan terima kasih atas bantuan 
dan saran-sarannya dalam teknik penulisan untuk artikel ini. Mereka telah memberikan banyak masukan dan koreksi dalam penulisan tesis dan juga dalam penulisan artikel ini. Ucapan terima kasih juga disampaikan kepada seluruh pihak yang telah membantu dan memberi kepercayaan untuk menyelesaikan penelitian ini tepat pada waktunya.

\section{Daftar Pustaka}

Butler, R.W.1980. The Concept of Tourism Area Cycle Of Evolution: Implications for the Management of Resources. The Canadian Geographer Vol. 24:5-12.

Hermanoro, Henky. 2011. Creative-Based Tourism: Dari Wisata Rekreatif Menuju Wisata Kreatif. Depok: Aditri.

Juhanda. 2004. "Formulasi Strategi Pengembangan Pariwisata di Kabupaten Situbondo" (Tesis). Denpasar: Pascasarjana Universitas Udayana.

Marpaung, Happy. 2002. Pengantar Pariwisata. Bandung: Alfabeta

Mill, Robert Christie. 2000. Tourism The International Business (Alih Bahasa Sastro Tribudi). Jakarta: PT Raja Grafindo Persada.

Pitana, I Gede dan Putu G. Gayatri. 2005. Sosiologi Pariwisata: Kajian Sosiologis Terhadap Struktur, Sistem, dan Dampak - dampak Pariwisata.Yogyakarta: ANDI.

Pitana, I Gede dan Surya Diarta, I Ketut. 2009. Pengantar Ilmu Pariwisata. Yogyakarta: ANDI.

Pogalad, Meikel, Silvana Sondak, Edwin Nani, Yenni Utiarahman, Triyanti Hunowu Moh Syarief Hida. 2009. Analisis Pengembangan Obyek Wisata (The Tourism Of Development) Terhadap Tingkat Kunjungan Wisatawan di Pentadio Resort Kabupaten Gorontal. Dinas Pariwisata Kebudayaan Komunikasi dan Informatika Kabupaten Gorontalo.

Putra, I Nyoman Darma dan I Gede Pitana. 2010. Pariwisata Pro-Rakyat Meretas Jalan Mengentaskan Kemiskinan di Indonesia. Jakarta: Kementerian Kebudayaan dan Pariwisata.

Rangkuti, Freddy. 2005. Analisis SWOT Teknik Membedah Kasus Bisnis. Jakarta: PT. Gramedia Pustaka.

Rencana Pembangunan Jangka Menengah Desa (RPJM Desa Bongo) 2011 Kecamatan Batudaa Pantai Kabupaten Gorontalo.

Undang-undang Republik Indonesia Nomor 10 Tahun 2009 Tentang Kepariwisataan. http://yotama-gorontalo.blogspot.com. Laporan Pokok Pikiran Yotama (Yosep Tahir Ma'ruf). Diakses pada tanggal 14 April 2014. 


\section{Profil Penulis}

Ramang Husin Demolingo, SS, M.Par, menyelesaikan pendidikan S-2 Kajian Pariwisata Universitas Udayana tahun 2015. Program S-1 yang ditempuh adalah Jurusan Sastra Inggris pada Fakultas Sastra Universitas Nasional Jakarta diselesaikan pada tahun 2004. Dia pernah mengikuti pendidikan dan pelatihan "Pemerintahan Yang Bersih" yang dilaksanakan oleh Direktorat Institute Singapura (SID) di Singapura pada November 2003. Kini, bekerja sebagai calon dosen di Fakultas Sastra dan Budaya Program Diploma III Pariwisata Universitas Negeri Gorontalo (UNG). 